
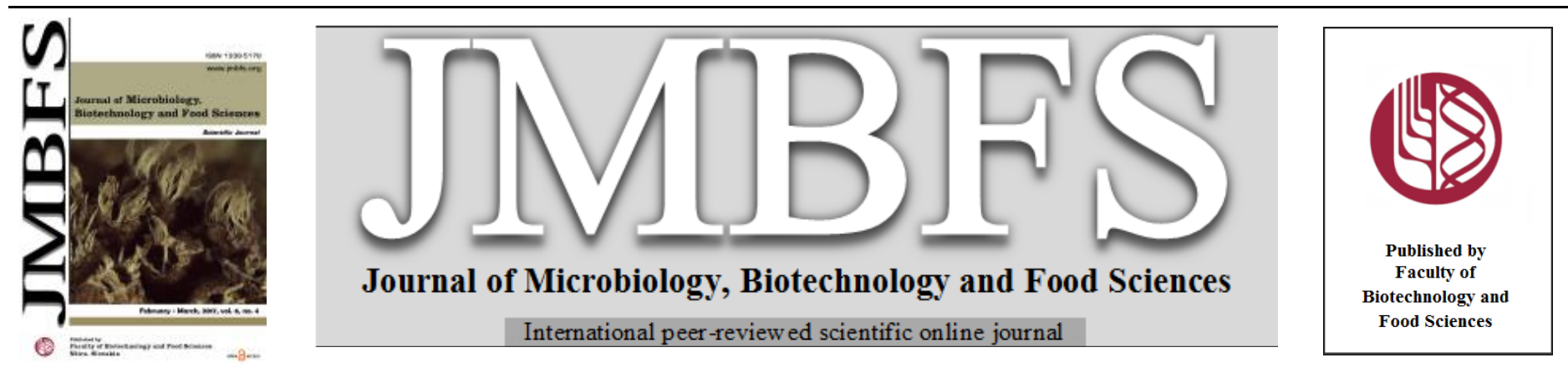

\title{
POLYPHASIC ANALYSIS OF TWO THERMOTOLERANT, AND EXOZYMES PRODUCING GEOBACILLUS SPECIES FROM HOT SPRING OF NEPAL
}

\author{
Hriush Adhikari $^{1,2 *}$, Sangam Ghimire ${ }^{1,2}$, Binod Khatri ${ }^{1,2}$, Yuvraj K.C ${ }^{l}$ \\ Address(es): Mr. Hriush Adhikari, \\ ${ }^{1}$ Department of Biotechnology, SANN International College and Research Center, Kathmandu, Nepal. \\ ${ }^{2}$ Nav- Inception: Biotech, Health, Environment Research Center. Kathmandu, Nepal.
}

*Corresponding author: mailforhriush@gmail.com

doi: $10.15414 / j m b f s .2017 .6 .4 .1059-1064$

\section{ARTICLE INFO}

Received 9. 6. 2016

Revised 7. 10. 2016

Accepted 11. 12. 2016

Published 1. 2. 2017

Regular article

OPEN $\partial_{\text {ACCESS }}$

\begin{abstract}
Background and Aim: Nepal's geothermal areas are considered as uncharted place for microbiological and biotechnological researchers since not many researches has been conducted on these areas. The main aim of this study was to isolate thermophilic bacteria from hostspring of Nepal. Methods: From one of the hottest natural thermal spring of Nepal, Bhurung Tatopani, 20 different bacteria were isolated and Characterized by both culture dependent and independent approaches. Results: Morphological and biochemical tests along with polyphasic analysis of these thermal isolates confirmed that two of these species belongs to Geobacillus sp. The isolates THG1 and THG2 were found to be gram variable and rod shaped with smooth colony. They were found to be osmotolerant up to $2 \% \mathrm{NaCl}$ and thermotolerant with optimum temperature of $72^{\circ} \mathrm{C}$. They showed significant production of various industrially important enzymes like amylase, lipase, protease and cellulase. 16S rRNA amplification was also performed and sequenced which revealed that the isolate THG1 has 99\% similarity with Geobacillus kaustophilus and THG2 has 99\% similarity with Geobacillus thermoleovorans. THG1 and THG2 16S rRNA sequences are deposited in genebank with accession id KP764939 and KP764940. For the further confirmation and deeper analysis, fatty acid analysis (FAME) was also performed and their fatty acid composition profile was also created. Conclusion: From the Bhurung hotspring two unique Geobacillus species were isolated.
\end{abstract}

Keywords: Bhurung Tatopani, Geobacillus, FAME, Thermotolerant

\section{INTRODUCTION}

Hot springs are unique hydrothermal features formed when underground water, heated due to geothermal energy. Generally hot springs discharge water which is heated by magma close to the earth's surface in volcanic areas. Some, however, are not related to volcanic activity. In such cases, the heating of water results from convective circulation and thermal springs from Nepal are examples of this type of phenomenon. More than twenty-eight geothermal manifestations occurs in Nepal, stretching right across a southeast-northwest elongated region. Some of the geochemical studies on these thermal springs have been conducted in the 80 's (Bhattarai and Bashyal, 1983; 3. Bhattarai,1980; 4. Bashysal, 1984). Geothermometer temperatures, ionic balance and discharge enthalpy has been calculated from the chemical data using the Program called WATCH (Arnorsson et al., 1982; Bjamason, 1994). Very few microbial and Biotechnological researches have been conducted in the Hot springs locations of Nepal. Since thermal springs are rich with numerous thermophiles, exploration of these microrganisms is needed for revealing the potentials of different thermophiles to be used through Biotechnology. Very few researches was conducted by NAST but not much of information was available in literature regarding presence of any noble and industrially potential thermophiles in various hotsprings. Adhikari et al. (2016) reported 15 different bacillus species from Bhurung tatopani with high extracellular enzyme production capacity and potential for industrial upgrades.

Apart from this, different exploration on hot springs located at different places of world has been conducted for isolating different important microorganisms. Many thermophilic bacterial strains were isolated from hot springs but the most common and significant finding in the field of thermophilic bacteria belongs to the genus Thermus (Brock and Freeze, 1969; Kristjansson and Alfredsson, 1983; Kristjansson et al., 1986; Kanasawud et al., 1992) Bacillus (Marsh and Larsen, 1952) and Nazina et al., (2001) rearranged and grouped Gram positive, rod-shaped, endospore-forming thermophilic bacilli into the genus Geobacillus. Geobacillus are unique bacterial species that are rod-shaped, occurring either singly or in short chains and motile by means of peritrichous flagella (Nazina $\boldsymbol{e t}$ al., 2001). Their cell wall structure is Gram-positive, but the Gram-stain reaction may vary between positive and negative. They can also be aerobic and sometimes facultative anaerobic. The growth temperature ranges from $37^{\circ} \mathrm{C}$ to $75^{\circ} \mathrm{C}$ with an optimum at $55^{\circ} \mathrm{C}$ to $65^{\circ} \mathrm{C}$. They have ability to grow at wide $\mathrm{pH}$ range of 6.0 to 8.5 with an optimum growth at $\mathrm{pH} 6.2$ to 7.5. Industrial interests in Geobacillus species has arisen from their potential applications in biotechnological processes, for example as sources of various thermostable enzymes, such as proteases (Sookkheo et al., 2000), amylases (Rao and Satyanarayana, 2003), lipases (Lee et al., 2001), pullanases (Messaoud et al., 2002) and xylanase (Sharma et al., 2007). Geobacillus species are widely distributed and readily isolated from different habitats (Nazina et al., 2001), with a rapid increasing industrial interest towards their thermostable gene products (Schallmey et al., 2004). Therefore, molecular characterization and study of its diversity with phylogenetic relations is not only regarded as a taxonomical concern, but is also a necessity for exploiting its biotechnological potential as a whole.

Nepal has a unique location which is diverse in extreme environments including the Highest mountain in the world, the lowest place on earth, in addition to several hot springs. Therefore, the aim of the current study was to isolate, identify and characterize thermophilic Geobacillus bacteria from 2 naturally occuring thermal springs in Bhurung, Nepal using phenotypic (morphological, physiological and biochemical) and genotypic methods (16S rRNA gene sequencing). Moreover, the extracellular thermostable enzymes of the obtained isolates were also identified.

\section{MATERIAL AND METHODS}

\section{Study site}

Bhurung Tatopani is located on Dhaulagiri Zone, Myagdi District, Singa V.D.C. Ward No 4. It is one of the hottest amongst 20 hot springs in Nepal and was a virgin area for microbial exploration. Heavy smell of sulphur gas and stale egg was present around the sources and upon close observation, the reservoir exhibited a green color. The study site was located at Latitude: $28^{\circ} 29^{\prime} 25.3^{\prime \prime}$ and Longitude: $83^{\circ} 37^{\prime} 54.06^{\prime \prime}$ with estimated terrain elevation 2262 meters above sea level. Though there are 3 different sources of hot springs, we chose two springs study site due to their high temperature and remote location. 


\section{Sample collection}

Insitu measurement of temperature and $\mathrm{pH}$ was performed within the sampling site. The water samples were collected in sterile glass vials and labeled individually. The sediments with the soil and microbial community were also collected in glass vials and kept into thermos without fluctuating temperature. All the vials were brought into SANN laboratory for further analysis.

\section{Enrichment and isolation}

Castenholz D basal salts medium supplemented with tryptone and yeast (TYE) was used as culture media with slight modifications. Water samples was inoculated into liquid medium and incubated at $72^{\circ} \mathrm{C}$ for $2-3$ days in a shaker incubator. Turbid cultures were spread on the same medium solidified with phytagel $(1-1.5 \%)$ and incubated at the same temperature until yellow or non pigmented colonies appear and can be isolated. After 2-3 days, yellow and colorless colonies easily observed were picked for further purification and analysis.

\section{Identification and characterization of the isolate}

The isolated strain's cell morphology and motility was examined by optica microscopy (BX40; Olympus) and growth characteristics were also studied on soild media. Based on Gram's staining the isolates were found to be Gramvariable and microscopic observation revealed rod shaped which are arranged in chain. Different biochemical tests like motility determination, endospore formation, catalase, IMViC, and oxidase tests were also performed.
Morphological observation and biochemical tests indicated that the isolated bacteria belonged to be Geobacillus sp. Similarly different physiological characterization was also performed for testing degree of osmotolerant, $\mathrm{pH}$ tolerant and thermotolerant. Determination of optimum growth by turbidity measurements was also performed.

\section{Extracellular enzyme production}

Bacterial isolates were screened for their ability to produce different thermostable extracellular enzymes like amylases, lipases and cellulases. The culture extracts grown in different single carbon source media at $70^{\circ} \mathrm{C}$ as well as freshly grown cultured of isolates was used for enzyme screening. Tween 80 NA medium was used to study lipase activity. Amylase activity was determined using starch agar plates and positive results was confirmed by incubating the plates and exposing to iodine solution. Similarly, Cellulase activity was studied on carboxy methyl cellulose (CMC 1\%) agar.

\section{Molecular identification}

Genomic DNA extraction was peformed using CTAB manual method as well as using promega DNA isolation kit and purified using protocol from Sambrook and Russell (Sambrook and Russell, 2001). In order to access its purity, UV spectrophotometry was performed at A260/A280 ratio. The extracted DNA was then used as template for amplifying the gene encoding for the 16S rDNA (Edwards et al., 1989) using bacterial universal primer.

Table 1 Universal primer for $16 \mathrm{~S}$ rRNA amplification

\begin{tabular}{lllll}
\hline Primer & Sequence (5'-3') & Primer length & GC\% & Sequence amplified \\
\hline 518F & CCAGCAGCCGCGGTAATACG & 20 & 65 & $1500 \mathrm{bp}$ \\
800R & TACCAGGGTATCTAATCC & 18 & 44.44 & $1500 \mathrm{bp}$ \\
\hline
\end{tabular}

The reaction volume of $25 \mu \mathrm{l}$ containing $2 \mathrm{ul}$ of $20 \mathrm{ng} / \mathrm{ul}$ template DNA, 1 unit of Tag DNA polymerase , $75 \mathrm{mM}$ of $\mathrm{MgCl} 2,200 \mu \mathrm{M}$ of DNTPs, $2.5 \mu \mathrm{l}$ of $10 \mathrm{X}$ PCR buffer and 5 pmol of each Primer. The Amplification protocol was programmed with $95^{\circ} \mathrm{C}$ for $5 \mathrm{~min}$ followed by 30 cycles of $95^{\circ} \mathrm{C}$ for $1 \mathrm{~min}, 55^{\circ} \mathrm{C}$ for $1 \mathrm{~min}, 72^{\circ} \mathrm{C}$ for $1 \mathrm{~min}$ and a final extension of $7 \mathrm{~min}$. Gel electrophoresis was performed using $2 \%$ agarose gel and the amplified amplicon was observed under the gel documentation system. The PCR products were purified using the Promega PCR purification Kit protocol according and sequenced in Macrogen Inc. Korea.

\section{Phylogenetic analysis}

The sequenced 16S rRNA sequences obtained from Macrogen were first manually edited using Sequencher Software 5.3 in order to remove ambiguity in the sequences. Since bidirectional sequencing was carried out, single contigs was built using the same software and exported as text format. The edited sequences were then compared with the nucleotide database using Basic Local Alignment Search Tool (BLAST) in the National Centre for Biotechnology Information (NCBI). The closest relatives (high similarity) with the query sequences were retrieved and aligned using MUSCLE. Aligned sequences were analysed and phylogenetic tree was constructed using Mega 6.0 (Tamura et al., 2013).

Neighbor-Joining method and maximum likelihood method (Saitou and Nei, 1987; Tamura et al., 2013) was used to show the evolutionary relationships of these taxa, The optimal tree with the sum of branch length $=0.81476834$ was drawn and the percentage of replicate trees in

which the associated taxa clustered together in the bootstrap test (1000 replicates) shown next to the branches. Bootstrap analysis using Mega 6, was performed to attach confidence estimates for the tree topologies (Felsenstein, 1985). The tree was drawn to scale, with branch lengths in the same units as those of the evolutionary distances used to infer the phylogenetic tree. Maximum Composite Likelihood method was used to compute the evolutionary distances.

Fame analysis

Bacterial isolates were also identified by using Sherlock Microbial Identification System (MIS), MIDI in Royal Life Science Pvt Ltd, India. This is a unique system that identifies microorganisms based on their fatty acid methyl ester (FAME) patterns. FAME profiles are then compared to a standard database and most likely hits are then presented to the user. The database includes aerobic bacteria, anaerobic bacteria and yeasts. These FAME's were analyzed using Gas Chromatography with the help of MIDI Sherlock software for FAME. Aerobic library (RTBSA 6.0) was referred for the analysis.

\section{RESULTS}

\section{Physical characteristics of sampling sites}

During sampling time there was a heavy smell of sulphur gas around the sources and the reservoir exhibited a green colour. The physical parameters at the source of thermal spring during the sampling of the thermal springs are mentioned in (Table 2). These values are the raw figures of the conditions at the sampling sites of the thermal waters at Bhurung tatopani during the sampling time.

Table 2 Physical parameters at the hot springs of Bhurung tatopani during the sampling time

\begin{tabular}{lcc}
\hline $\begin{array}{l}\text { Sampling /Conditions } \\
\text { parameters }\end{array}$ & Source 1 & Source 2 \\
\hline Atmospheric temperature $\left({ }^{\circ} \mathrm{C}\right)$ & 18 & 18 \\
Hot spring water temperature & 58 & 70 \\
$\left({ }^{\circ} \mathrm{C}\right)$ & 55 & 65 \\
Stream waterway temperature & 2262 meters & 2262 meters \\
$\left({ }^{\circ} \mathrm{C}\right)$ & 7.5 & 8.2 \\
Surface elevation & 1 & 1 \\
$\mathrm{pH}$ & $28^{\circ} 29^{\prime} 25.3^{\prime \prime} \mathrm{N} /$ & $28^{\circ} 29^{\prime} 25.3^{\prime \prime} \mathrm{N} /$ \\
Conductivity & $83^{\circ} 37^{\prime} 54.06^{\prime \prime} \mathrm{E}$ & $83^{\circ} 37^{\prime} 54.066^{\prime \prime} \mathrm{E}$ \\
& &
\end{tabular}

\section{Morphological characterization of isolates}

Table 3 Morphological characterization of isolates

\begin{tabular}{lccc}
\hline Strains & Colony colour & Cell shape & Gram reaction \\
\hline THG-1 & Yellow & rod & variable \\
THG-2 & Yellow & rod & variable \\
\hline
\end{tabular}

\section{Physiological characterization}

\section{Growth at various concentration of sodium chloride}

Table 4 Growth of thermophilic isolates from the hot springs of Bhurung at varied $\mathrm{NaCl}$ concentration.

\begin{tabular}{lcccccc}
\multirow{2}{*}{ Strains } & $\mathbf{0 \%}$ & $\mathbf{1 \%}$ & $\mathbf{2 \%}$ & $\mathbf{3 \%}$ & $\mathbf{4 \%}$ & $\mathbf{5 \%}$ \\
& Nacl & Nacl & Nacl & Nacl & Nacl & Nacl \\
\hline \multirow{2}{*}{ THG1 } & +++ & +++ & ++ & - & - & - \\
THG2 & +++ & +++ & + & - & - & - \\
\hline \multicolumn{2}{l}{ Legend: +++ High growth,++} & Moderate & growth, - Negative growth
\end{tabular}




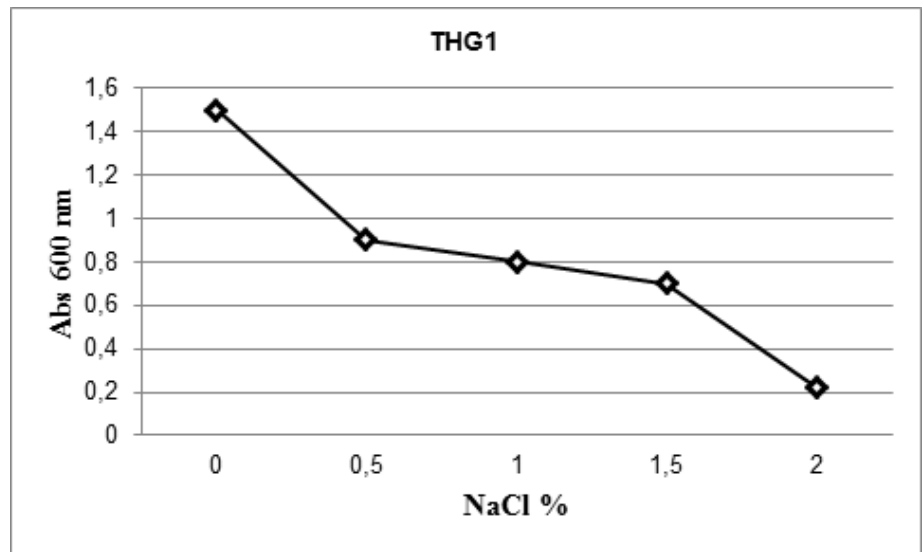

Figure 1 Determination of optimum salt concentration of THG1

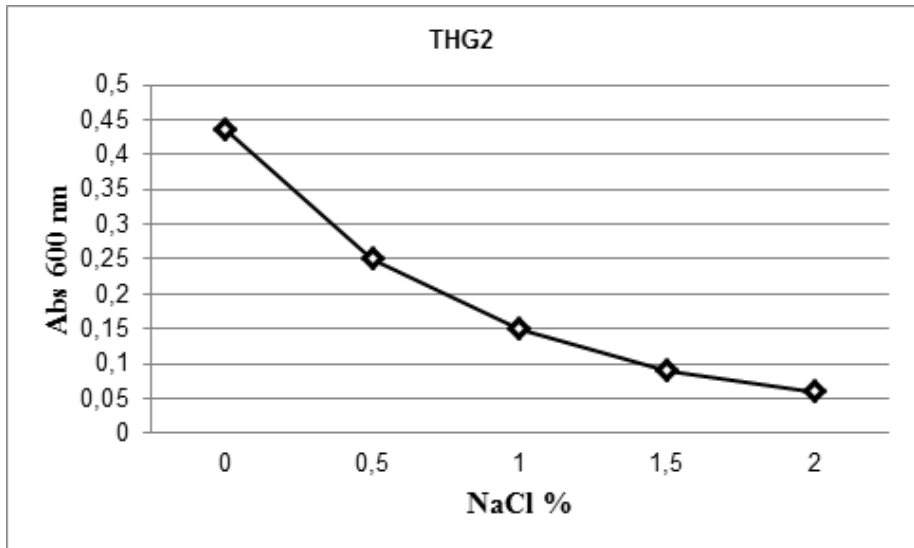

Figure 2 Determination of optimum salt concentration of THG2

\section{Growth of isolates at different temperature}

Table 5 Growth of thermophilic isolates from the hot springs of Bhurung at varied temperature.

\begin{tabular}{lccccccc} 
Temp & $\mathbf{3 5}^{\circ} \mathrm{C}$ & $\mathbf{4 5}^{\circ} \mathrm{C}$ & $\mathbf{5 5}^{\circ} \mathrm{C}$ & $\mathbf{6 5}^{\circ} \mathrm{C}$ & $\mathbf{7 0}^{\circ} \mathrm{C}$ & $\mathbf{7 5}^{\circ} \mathrm{C}$ & $\mathbf{8 0}^{\circ} \mathrm{C}$ \\
Strains & & & & & & & \\
\hline THG1 & - & + & + & + & +++ & + & - \\
THG2 & - & + & + & + & +++ & + & -
\end{tabular}

Legend: +++ High growth , + Moderate growth, - Negative growth

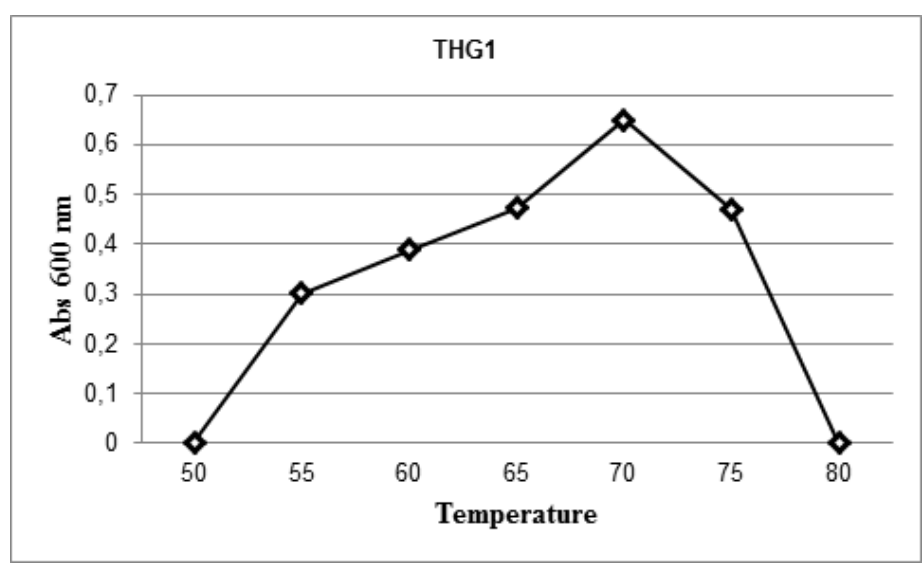

Figure 3 Determination of optimum temperature for THG1
THG2

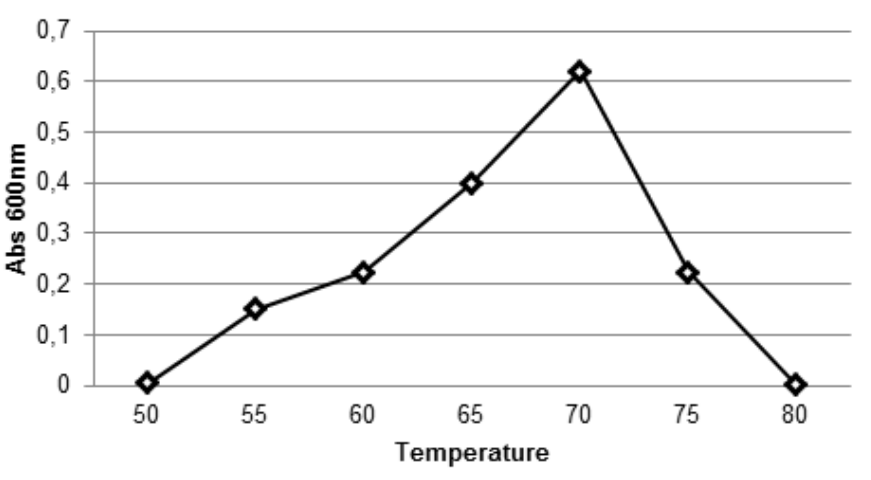

Figure 4 Determination of optimum temperature for THG2

\section{EFFECT OF ph ON THE ISOLATES}

Table 6 Growth of thermophilic isolates from the hot springs of Bhurung Tatopani at varied $\mathrm{pH}$.

\begin{tabular}{llllll}
\hline pH & 5 & 6 & 7 & 8 & 9
\end{tabular}

\begin{tabular}{cccccc}
\hline THG1 & - & - & ++ & +++ & - \\
THG2 & - & - & ++ & +++ & - \\
\hline Legend: & +++ High growth & + Moderate growth, & - Negative growth
\end{tabular}

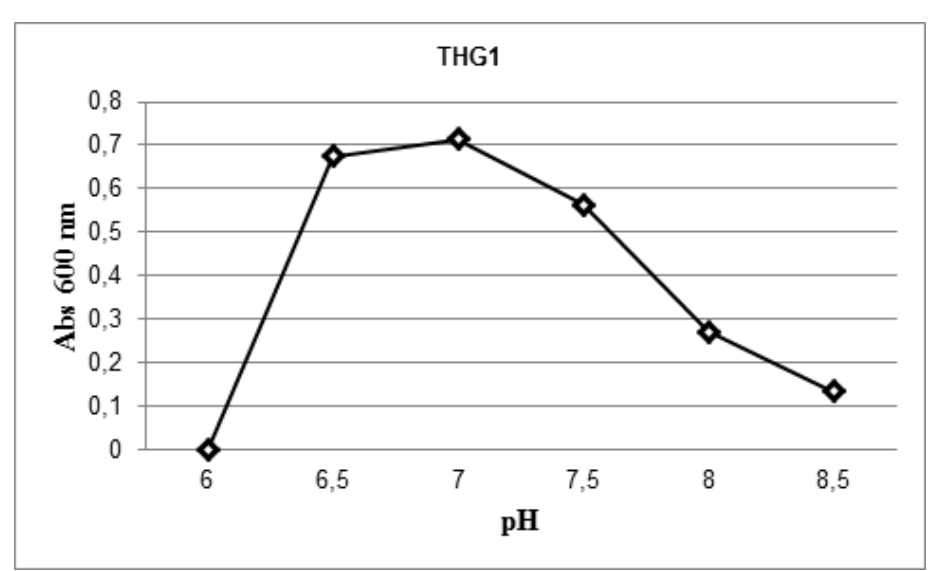

Figure 5 Determination of optimum $\mathrm{pH}$ for THG1

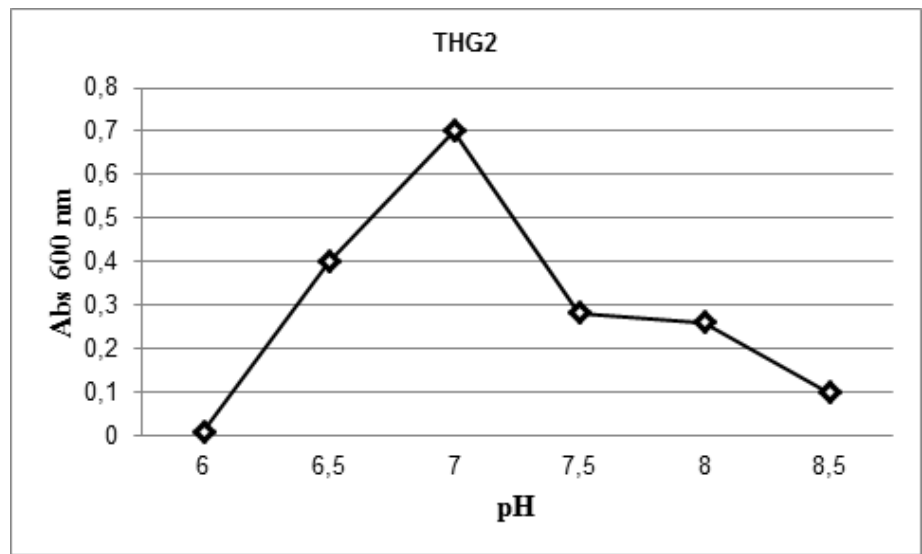

Figure 6 Determination of optimum $\mathrm{pH}$ for THG2 
Determination of optimum growth of two strains by turbidity measurements
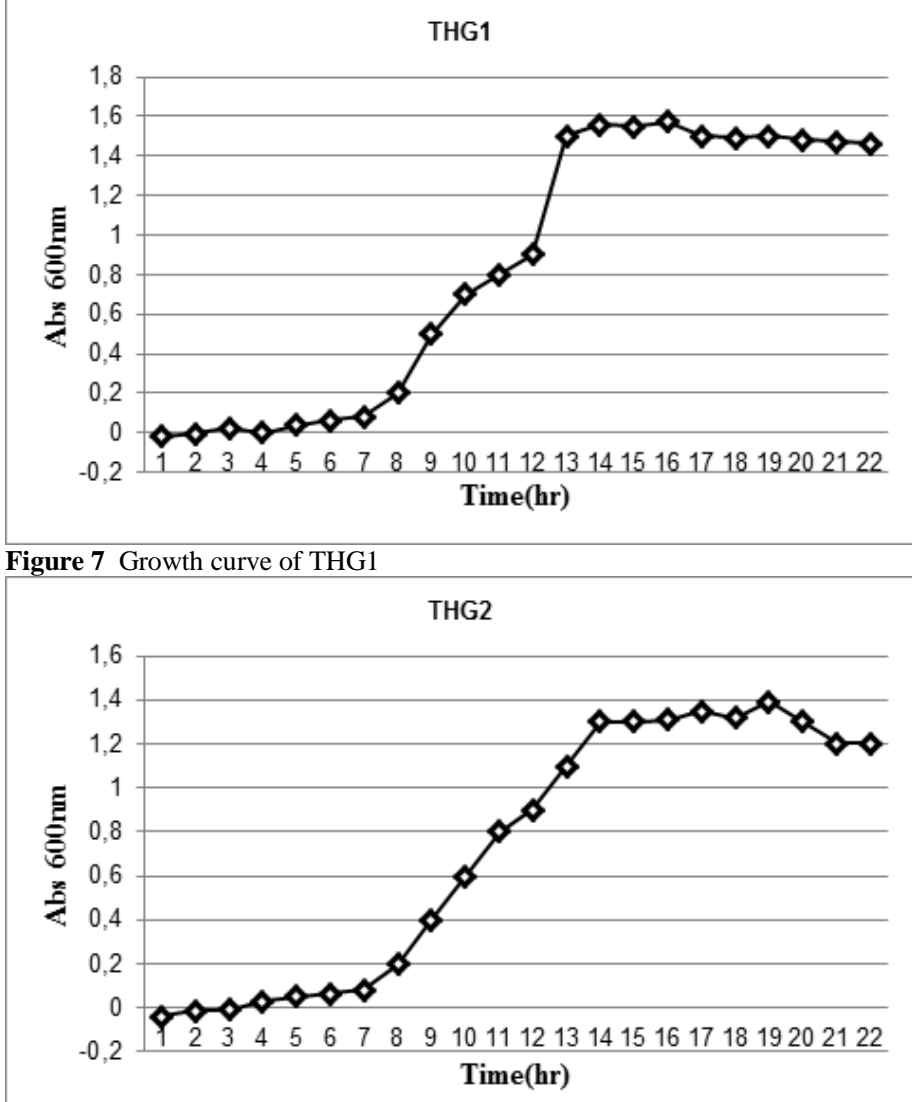

Figure 8 Growth curve of THG2

\section{Biochemical characterization}

Table 7 Biochemical characteristics of strains THG1 and THG2

\begin{tabular}{|c|c|c|}
\hline Characteristics & THG1 & THG2 \\
\hline Pigmentation & Yellow & Yellow \\
\hline Colonies & Compact & Compact \\
\hline Optimum Temp ${ }^{\circ} \mathrm{C}$ & 70 & 70 \\
\hline \multicolumn{3}{|l|}{ Growth at/on: } \\
\hline Growth in $1 \%$ Nacl & + & + \\
\hline Growth in $3 \%$ Nacl & - & - \\
\hline \multicolumn{3}{|l|}{ Presence of: } \\
\hline Oxidase & + & + \\
\hline Catalase & $-/+$ & + \\
\hline ß-Galactosidase & + & + \\
\hline Urease & - & - \\
\hline \multicolumn{3}{|l|}{ IMVIC } \\
\hline Indole & - & - \\
\hline MR/VP & - & - \\
\hline Citrate & + & + \\
\hline \multicolumn{3}{|l|}{ Hydrolysis of : } \\
\hline Starch & + & + \\
\hline Gelatin & + & + \\
\hline Casein & + & + \\
\hline Tween 20 & + & + \\
\hline \multicolumn{3}{|l|}{ Utilization of: } \\
\hline D-Glucose & + & + \\
\hline D-Fructose & + & + \\
\hline D-Galactose & + & + \\
\hline D-Xylose & + & + \\
\hline D-Mannose & nd & nd \\
\hline Cellulose & + & + \\
\hline Lactose & + & + \\
\hline Sucrose & - & - \\
\hline Raffinose & - & - \\
\hline
\end{tabular}

Citrate

Arginine

Proline

Ornithine

L-Serine

Glycerol

Sensitive to:

Amoxicillin $(10 \mu \mathrm{g})$

Ampicillin $(10 \mu \mathrm{g})$

Neomycin $(30 \mu \mathrm{g})$

Oxacillin $(10 \mu \mathrm{g})$

Penicillin(10IU)

Streptomycin $(10 \mu \mathrm{g})$

Vancomycin $(30 \mu \mathrm{g})$

DNA G+C content

$(\mathrm{mol} \%)$

\begin{tabular}{lc}
+ & + \\
+ & + \\
+ & + \\
+ & + \\
+ & + \\
+ & + \\
+ & + \\
+ & + \\
+ & - \\
- & + \\
+ & + \\
+ & + \\
+ & 59.022 \\
\hline 9.77 & + \\
\hline
\end{tabular}

Legend: + Positive result; - Negative result or No growth; nd-not determined.

Enzyme production

Table 8 Detection of extracellular enzymes for the 2 isolates at $70^{\circ} \mathrm{C}$.

\begin{tabular}{cccc}
\hline Isolate & $\begin{array}{c}\text { Amalyse activity at } \\
\mathbf{7 0}^{\circ} \mathbf{C}\end{array}$ & $\begin{array}{c}\text { Cellulase activity at } \\
\mathbf{7 0}^{\circ} \mathbf{C}\end{array}$ & $\begin{array}{c}\text { Lipase activity at } \\
\mathbf{7 0}^{\circ} \mathbf{C}\end{array}$ \\
\hline THG1 & Very good & Very good & Good \\
THG2 & Excellent & Very good & Excellent \\
\hline
\end{tabular}

Molecular characterization

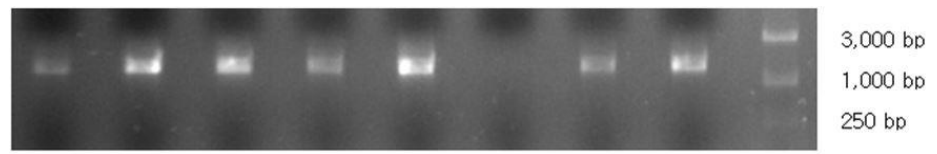

$\begin{array}{lllll}\mathrm{T} 1 & \mathrm{~T} 2 & \mathrm{~T} 3 & \mathrm{~T} 4 & \mathrm{~T} 5\end{array}$

Figure 9 A photograph of amplified 16S rRNA $(1.5 \mathrm{~kb})$ of gram negative bacteria using forward primers and reverse from thermophiles isolated from the hot springs of Bhurung tatopani

Table 9 Blast search results of the sequenced isolates from the hot springs of Bhurung tatopani and their close relatives.

\begin{tabular}{|c|c|c|c|}
\hline Isolate & $\begin{array}{l}\text { Blast results (Close } \\
\text { relatives) }\end{array}$ & $\begin{array}{l}\text { Percentage } \\
\text { Similarity }\end{array}$ & $\begin{array}{l}\text { Genbank Acession } \\
\text { number }\end{array}$ \\
\hline THG1 & $\begin{array}{l}\text { Geobacillus } \\
\text { kaustophilus }\end{array}$ & $99 \%$ & KP764939 \\
\hline THG2 & $\begin{array}{l}\text { Geobacillus } \\
\text { thermoleovorans }\end{array}$ & $99 \%$ & KP764940 \\
\hline
\end{tabular}

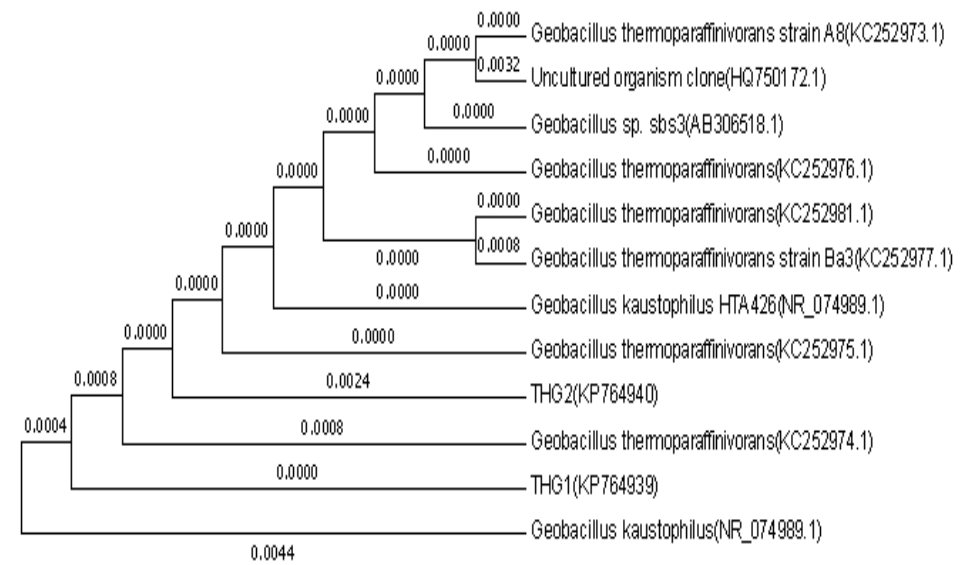

Figure 10 Maximum likelihood distance tree using 16S rRNA sequences of Geobacillus strains isolated from the hot springs of Bhurung tatopani and closest relatives. Bootstrap values as percentages of 1000 replicates are given at branch points; only values $>50 \%$ are shown.

\section{Fame identification}

FAME analysis strains THG1 and THG2 was performed In Royal Life Science, India. They had higher combined levels of C15:0 iso, C15:0 anteiso, C16:0 and C17:0 compared with their closest relatives. 
Table 10 Fatty acid composition of strains THG1 and THG2.

\begin{tabular}{|c|c|c|}
\hline Fatty acid & THG1 & $\underline{\text { THG2 }}$ \\
\hline $12: 0$ & 2.07 & 1.29 \\
\hline 11:03OH & ---- & 0.27 \\
\hline $13: 0$ iso & 0.94 & 0.80 \\
\hline 13:0 anteiso & 0.89 & 0.18 \\
\hline $14: 0$ iso & 3.72 & 1.0 \\
\hline $14: 0$ & 1.29 & 1.4 \\
\hline $15: 1$ iso $G$ & ---- & 0.77 \\
\hline 15:1 anteiso $A$ & 0.52 & 1.3 \\
\hline $15: 0$ iso & 25.73 & 22.6 \\
\hline $15: 0$ anteiso & 12.75 & 9.43 \\
\hline $15: 0$ & ---- & 2.1 \\
\hline $16: 1 \mathrm{w} 7 \mathrm{c}$ alcohol & 1.49 & 1.09 \\
\hline 16:0 N alcohol & 1.38 & 0.19 \\
\hline $16: 0$ iso & 9.03 & 14.96 \\
\hline $16: 1 \mathrm{w} 9 \mathrm{c}$ & --- & 21.2 \\
\hline $16: 0$ & 6.91 & 11.2 \\
\hline $17: 1$ iso $\mathrm{w} 10 \mathrm{c}$ & 3.24 & 1.83 \\
\hline $17: 0$ iso & 15.70 & 18.5 \\
\hline $17: 0$ anteiso & 6.77 & 4.6 \\
\hline $17: 0$ & 1.74 & 1.70 \\
\hline $18: 0$ iso & 0.75 & 0.72 \\
\hline $18: 1 \mathrm{w} 9 \mathrm{c}$ & 4.25 & 1.14 \\
\hline $18: 0$ & 2.27 & 3.4 \\
\hline $17: 0$ iso $3 \mathrm{OH}$ & 0.34 & 0.13 \\
\hline 18:0 10-methyl, TBSA & 0.14 & 0.14 \\
\hline $18: 02 \mathrm{OH}$ & 0.25 & 0.16 \\
\hline 19:0 & 0.13 & ---- \\
\hline 20:0 & 0.18 & ---- \\
\hline $20: 0$ iso & 0.22 & ---- \\
\hline
\end{tabular}

\section{DISCUSSION}

The objectives of this research were to determine the physio-chemical characteristics of the hot springs in Bhurung tatopani, isolate a large number of useful thermophiles from the hot springs, characterize and identify them using morphological, physiological, biochemical and molecular methods and then to screen the isolates for useful enzyme production.

Thermal springs of Bhurung tatopani have extreme physico-chemical conditions (Table 1) suitable for the thermophiles such as Bacillus, Geobacillus and Thermus species. A total of 20 isolates were isolated from the hot springs of Bhurung tatopani, 15 belonged to Bacillus genus (paper pertaining this research is already published and can be retrieved online), 2 belonged to Geobacillus and 3 belonged to Thermus genus thermophiles. Castenholz TYE media was used to increase the chances of isolation of thermophiles. The media was modified by addition of different concentration of sodium chloride and varying the carbon source with glucose, starch and cellulose Also phytagel was used as a gelling agent instead of agar. Comparing to agar, phytagel was required in half amount and gave strong gel after solidifying.

However, the isolates showed a low diversity within morphotypes recovered since most isolates represented the same bacterium i.e. bacillus. This could be attributed to the fact that cultivation is known to capture a small segment of microbial diversity in a given sample. The low diversity of isolates obtained from water sampled at Bhurung hot springs could be due to the fact that very low diversity in hot environments is common. Most of them are distributed in many mesophilic environments, but others have been isolated only from one specific location. It remains possible that there are other strains of thermophiles present in Bhurung tatopani thermal water but since two extreme conditions were imposed at the same time; (high $\mathrm{pH}$ and elevated temperature), low diversity was achieved. The combination of two extreme conditions of physio-chemical growth parameters restricts the range at which microorganisms can proliferate more than in a single growth condition.

Microbial enzyme occupies a valuable position in modern biotechnology. The majority of the industrial enzymes known to date have been derived from bacteria and fungi (Haki and Rakshit, 2003). Therefore isolation and study of these thermophilic microbes is an vital task for modern scientist. We recorded very significant Amylase and Cellulase activity including others in the isolated strains The sequence comparison showed that the query sequence coverage was almost $100 \%$ and identity was above $99 \%$ with the database sequence. What will be the next line of development, is unclear (Horikoshi, 1999), but it might be the wider application of enzymes. Alkaline and thermostable enzymes should provide additional uses in various fields of industry, such as chiral-molecule synthesis, biological wood pulping, and more production of sophisticated enzyme detergents. It is expected that in the near future, further aerobic and anaerobic thermophiles with intriguing properties will be isolated from extreme environments using traditional and novel microbial culture techniques and molecular analysis such as metagenomics. These studies will, extend our understanding of the boundaries for conditions under which life can thrive on earth (Kevbrin et al., 1998). Subsequently, this will lead to noble theories of how life could have evolved on early earth and whether it could presently or in the future exist in extraterrestrial habitats.

\section{CONCLUSION}

The thermal hot springs of Bhurung Tatopani have an average temperature of 65 $75^{\circ} \mathrm{C}$ and an average $\mathrm{pH}$ of 7.5-9 which are extreme conditions suitable for the inhabitation of thermophiles such as Bacillus, Geobacillus and Thermus species. By the use of the Castenholz TYE media and with the help of phytagel as a gelling agent, varying the carbon source (cellulose, xylan, starch and glucose), two Geobacillus species were isolated. All The 16S rRNA partial sequences of the these two isolates have been deposited into genebank with genbank Id KP764939 and KP764940 respectively. Detailed biochemical and molecular characterization of the isolated Geobacillus strains was performed and Fatty acid profiling was also performed.

The isolates were thermotolerant, and alkalitolerant because they grew at wide range of temperature $\left(45^{\circ} \mathrm{C}-75^{\circ} \mathrm{C}\right), \mathrm{pH}(5.7-8.0)$ and $\mathrm{NaCl}$ concentration $(0-2 \%)$ and therefore able to survive in extreme conditions. The thermophiles isolated from the hot springs of Bhurung tatopani were able to produce various thermostable extracellular enzymes like cellulose, lipase, amylase and protease. The sequence information obtained from PCR and sequencing was very good enough for the molecular analysis and identification. For enchancement of the optimum extracellular enzymatic activity further optimization of growth parameters can be performed. Further research is required to design studies that would compare the diversity among thermophiles in different seasons of the year such as the rainy and dry seasons. Different protocols and novel microbial culture techniques should be designed so as to allow the isolation of more diverse genera Extensive research on the specific secondary metabolites released by thermophiles from the hot springs should be done.

Acknowledgements: We would like to extend our gratitude towards Prof. Dr. Mukunda Ranjit, Er. Dilip Bhattarai and all the staffs of Department of Biotechnology, SANN International College, Gairidhara, Kathmandu, Nepal for providing all the support during study period. We would also like to thank the local people of Bhurung tatopani for their hospitability and guidance during sample collection and site survey.

Competing interests: There are no competing interests.

\section{REFERENCES}

Adhikari, H., Ghimire, S., Khatri, B., \& Yuvraj, K. C. (2015). Enzymatic Screening and Molecular Characterization of Thermophilic Bacterial Strains Isolated from Hotspring of Tatopani, Bhurung, Nepal. International Journal of Applied Sciences and Biotechnology, 3(3), 392-397. http://dx.doi.org/10.3126/ijasbt.v3i3.12724

Arnórsson, S., Sigurdsson, S., \& Svavarsson, H. (1982). The chemistry of geothermal waters in Iceland. I. Calculation of aqueous speciation from 0 to $37^{\circ} \mathrm{C}$. Geochimica et Cosmochimica Acta, 46(9), 1513-1532. http://dx.doi.org/10.1016/0016-7037(82)90311-8

Bashyal. RP. (1984) Preliminary Investigation o/Thermal Springs of Darchula and Bajhang Distric. H.M.G. Department of Mines and Geology, Kathmandu, internal report, $17 \mathrm{pp}$.

Bhattarai, D.R, and Bashyal, RP. (1983) Preliminary investigation of thermal springs in Jumla and Jomsom areas. HMG Department or Mines and Geology, Kathmandu, intermal report, $18 \mathrm{pp}$.

Bhattarai, D.R. (1980) Some geothermal manifestations of Nepal. Tectonophysics, 62,7.11.http://dx.doi.org/10.1016/0040-1951(80)90071-2

Bjamason, 1O.,(1994): The speciation program WATCH, version 2.1 Orkustofnun, Reykjavik, 7 pp.

Brock, T. D., \& Freeze, H. (1969). Thermus aquaticus gen. n. and sp. n., a nonsporulating extreme thermophile. Journal of bacteriology, 98(1), 289-297.

Edwards, U., Rogall, T., Blöcker, H., Emde, M., \& Böttger, E. C. (1989) Isolation and direct complete nucleotide determination of entire genes. Characterization of a gene coding for $16 \mathrm{~S}$ ribosomal RNA. Nucleic Acids Research, 17(19), 7843-7853.

Felsenstein, J. (1985). Confidence limits on phylogenies:an approach using the bootstrap. Evolution, 783-791. http://dx.doi.org/10.2307/2408678 
Haki, G. D., \& Rakshit, S. K. (2003). Developments in industrially important thermostable enzymes: a review. Bioresource technology, 89(1), 17-34. http://dx.doi.org/10.1016/s0960-8524(03)00033-6

Horikoshi, K. (1999). Alkaliphiles: some applications of their products for biotechnology. Microbiology and molecular biology reviews, 63(4), 735-750. http://dx.doi.org/10.1007/978-94-011-2274-0 5

Kanasawud, P., Teeyapan, S., Lumyong, S., Holst, O., \& Mattiasson, B. (1992). Thermus $2 \mathrm{~S}$ from Thai hot springs: isolation and immobilization.World Journal of Microbiology and Biotechnology, 8(2), 137-140. http://dx.doi.org/10.1007/bf01195833

Kevbrin, v., Romanek, c. and Wiegel, j. (1998) Alkalithermophiles: a double challenge from extreme environment. Biochemical Society Transaction, 1: 1-16. http://dx.doi.org/10.1007/1-4020-2522-x_24

Kristjansson, J. K., \& Alfredsson, G. A. (1983). Distribution of Thermus spp. in Icelandic hot springs and a thermal gradient. Applied and environmental microbiology, 45(6), 1785-1789. http://dx.doi.org/10.1016/s07232020(85)80037-0

Kristjansson, J. K., Hreggvidsson, G. O., \& Alfredsson, G. A. (1986). Isolation of halotolerant Thermus spp. from submarine hot springs in Iceland.Applied and environmental microbiology, 52(6), 1313-1316.

Lee, D. W., Kim, H. W., Lee, K. W., Kim, B. C., Choe, E. A., Lee, H. S., ... \& Pyun, Y. R. (2001). Purification and characterization of two distinct thermostable lipases from the gram-positive thermophilic bacterium Bacillus thermoleovorans ID-1. Enzyme and Microbial Technology, 29(6), 363-371. http://dx.doi.org/10.1016/s0141-0229(01)00408-2

Marsh, C. L., \& Larsen, D. H. (1953). Characterization of some thermophilic bacteria from the hot springs of Yellowstone National Park. Journal of bacteriology, 65(2), 193.

Messaoud, E. B., Ammar, Y. B., Mellouli, L., \& Bejar, S. (2002). Thermostable pullulanase type I from new isolated Bacillus thermoleovorans US105: cloning, sequencing and expression of the gene in E. coli. Enzyme and microbial technology, 31(6), 827-832. http://dx.doi.org/10.1016/s0141-0229(02)00185-0

Nazina, T. N., Tourova, T. P., Poltaraus, A. B., Novikova, E. V., Grigoryan, A. A., Ivanova, A. E., \& Ivanov, M. V. (2001). Taxonomic study of aerobic thermophilic bacilli: descriptions of Geobacillus subterraneus gen. nov., sp. nov. and Geobacillus uzenensis sp. nov. from petroleum reservoirs and transfer of Bacillus stearothermophilus, Bacillus thermocatenulatus, Bacillus thermoleovorans, Bacillus kaustophilus, Bacillus thermodenitrificans to Geobacillus as the new combinations G. stearothermophilus, G. th. International Journal of Systematic and Evolutionary Microbiology, 51(2), 433-446. http://dx.doi.org/10.1099/00207713-51-2-433

Saitou, N., \& Nei, M. (1987). The neighbor-joining method: a new method for reconstructing phylogenetic trees. Molecular biology and evolution, 4(4), 406425.

Sambrook, J. and Rusell, D.W. (2001). Molecular cloning: A laboratory manual, third ed. Cold Spring Harbor Laboratory, Cold Spring Harbor, New York, pp. $1.31-1.125$.

Schallmey, M., Singh, A., \& Ward, O. P. (2004). Developments in the use of Bacillus species for industrial production. Canadian journal of microbiology,50(1), 1-17. http://dx.doi.org/10.1139/w03-076

Sharma, A., Adhikari, S., \& Satyanarayana, T. (2007). Alkali-thermostable and cellulase-free xylanase production by an extreme thermophile Geobacillus thermoleovorans. World Journal of Microbiology and Biotechnology, 23(4), 483490. http://dx.doi.org/10.1007/s11274-006-9250-1

Sookkheo, B., Sinchaikul, S., Phutrakul, S., \& Chen, S. T. (2000). Purification and characterization of the highly thermostable proteases from Bacillus stearothermophilus TLS33. Protein expression and purification,20(2), 142-151. http://dx.doi.org/10.1006/prep.2000.1282

Tamura, K., Stecher, G., Peterson, D., Filipski, A., \& Kumar, S. (2013). MEGA6: molecular evolutionary genetics analysis version 6.0. Molecular biology and evolution, mst197. http://dx.doi.org/10.1093/molbev/mst197

Uma Maheswar Rao, J. L., \& Satyanarayana, T. (2003). Enhanced secretion and low temperature stabilization of a hyperthermostable and $\mathrm{Ca} 2+$-independent $\alpha$ amylase of Geobacillus thermoleovorans by surfactants. Letters in applied microbiology, 36(4), 191-196. $\quad$ http://dx.doi.org/10.1046/j.1472- 